OPEN ACCESS

Edited by:

Mats Bemark,

University of Gothenburg, Sweden

Reviewed by:

Wim Van Den Broeck, Ghent University, Belgium

Claudio Nicoletti,

University of Florence, Italy

*Correspondence:

Manel Jordana

jordanam@mcmaster.ca

Specialty section:

This article was submitted to

Mucosal Immunity,

a section of the journal

Frontiers in Immunology

Received: 25 September 2019

Accepted: 21 January 2020

Published: 13 February 2020

Citation:

Jiménez-Saiz R, Anipindi VC,

Galipeau H, Ellenbogen Y,

Chaudhary R, Koenig JF, Gordon ME,

Walker TD, Mandur TS, Abed S,

Humbles A, Chu DK, Erjefält J, Ask K,

Verdú EF and Jordana M (2020)

Microbial Regulation of Enteric

Eosinophils and Its Impact on Tissue

Remodeling and Th2 Immunity.

Front. Immunol. 11:155.

doi: 10.3389/fimmu.2020.00155

\section{Microbial Regulation of Enteric Eosinophils and Its Impact on Tissue Remodeling and Th2 Immunity}

\author{
Rodrigo Jiménez-Saiz ${ }^{1,2}$, Varun C. Anipindi ${ }^{1}$, Heather Galipeau ${ }^{3}$, Yosef Ellenbogen ${ }^{1}$, \\ Roopali Chaudhary ${ }^{1}$, Joshua F. Koenig ${ }^{1}$, Melissa E. Gordon ${ }^{1}$, Tina D. Walker ${ }^{1}$, \\ Talveer S. Mandur ${ }^{1}$, Soumeya Abed ${ }^{1}$, Alison Humbles ${ }^{4}$, Derek K. Chu ${ }^{5}$, Jonas Erjefält ${ }^{6,7}$, \\ Kjetil Ask ${ }^{1}$, Elena F. Verdú ${ }^{3}$ and Manel Jordana ${ }^{1 *}$ \\ 1 Department of Pathology \& Molecular Medicine, McMaster Immunology Research Centre (MIRC), McMaster University, \\ Hamilton, ON, Canada, ${ }^{2}$ Department of Immunology \& Oncology, National Center for Biotechnology (CNB)-CSIC, Madrid, \\ Spain, ${ }^{3}$ Farncombe Family Digestive Health Research Institute, McMaster University, Hamilton, ON, Canada, ${ }^{4}$ Department of \\ Respiratory, Inflammation and Autoimmunity, Medlmmune, Gaithersburg, MD, United States, ${ }^{5}$ Department of Medicine, \\ McMaster University, Hamilton, ON, Canada, ${ }^{6}$ Department of Experimental Medical Science, Lund University, Lund, Sweden, \\ ${ }^{7}$ Department of Respiratory Medicine and Allergology, Lund University Hospital, Lund, Sweden
}

Eosinophils have emerged as multifaceted cells that contribute to tissue homeostasis. However, the impact of the microbiota on their frequency and function at mucosal sites remains unclear. Here, we investigated the role of the microbiota in the regulation of enteric eosinophils. We found that small intestinal (SI) eosinophilia was significantly greater in germ-free (GF) mice compared to specific pathogen free (SPF) controls. This was associated with changes in the production of enteric signals that regulate eosinophil attraction and survival, and was fully reversed by complex colonization. Additionally, SI eosinophils of GF mice exhibited more cytoplasmic protrusions and less granule content than SPF controls. Lastly, we generated a novel strain of eosinophil-deficient GF mice. These mice displayed intestinal fibrosis and were less prone to allergic sensitization as compared to GF controls. Overall, our study demonstrates that commensal microbes regulate intestinal eosinophil frequency and function, which impacts tissue repair and allergic sensitization to food antigens. These data support a critical interplay between the commensal microbiota and intestinal eosinophils in shaping homeostatic, innate, and adaptive immune processes in health and disease.

Keywords: eosinophils, microbiota, tissue remodeling, small intestine, allergy, germfree, IgE

\section{INTRODUCTION}

Eosinophils have traditionally been described as effector inflammatory cells that are protective against parasitic infections but detrimental in allergic disease $(1,2)$. New evidence has considerably broadened this paradigm as eosinophils have now been shown to play complex roles in mucosal immunity and tissue remodeling (3-8). For example, intestinal eosinophils and eosinophil peroxidase (EPO) are critical for the initiation of Th2 responses (IgE) to food allergens in the gastrointestinal (GI) tract $(6,9)$. Furthermore, intestinal accumulation of eosinophils has been associated with the severity of inflammatory bowel disease (IBD) $(10,11)$. Conversely, intestinal eosinophils secrete large quantities of IL-1 receptor antagonist, thus reducing inflammation in IBD $(12,13)$. Eosinophils have also been proposed to play a role in homeostatic tissue remodeling as 
their presence is increased at tissues with a high turnover such as the intestine and the uterus $(4,14)$. Eosinophils are equipped with damage-sensing receptors the ligation of which leads to the production of factors involved in tissue repair (e. g., TGF$\alpha$ and $-\beta$, vascular-endothelial growth factor (VEGF), etc.) (15). Hence, deciphering the factors that regulate eosinophils in the GI mucosa is relevant to understanding their role in health and disease.

There is growing evidence on the role of the microbiota in regulating immune responses and maintaining intestinal homeostasis $(16,17)$. Studies in germ-free (GF) mice have demonstrated that the microbiota is crucial for the maturation of the adaptive immune system in the small intestine (SI) (18). For example, GF mice have fewer $\mathrm{CD} 4^{+} \mathrm{T}$ cells, intraepithelial lymphocytes, and lower IgA-producing plasma cells in the lamina propria (LP) of the SI as compared to specific pathogen free (SPF) mice $(16,17,19,20)$. Yet, knowledge on the effect of the microbiota on innate cells that are indigenous to the intestinal tract, such is eosinophils, is scarce $(13,21)$.

Here we examined the impact of the microbiota on eosinophil frequency and function in the SI. We found that eosinophil frequency was enriched along the SI of GF mice relative to SPF controls. This was associated with local changes in the production of signals involved in the attraction, retention and survival of eosinophils. This relative eosinophilia was also observed in other mucosal sites, but not in sterile tissues, and was corrected by repletion of microbiota through co-habitation with altered Schaedler flora (ASF)- or SPF-mice. Additionally, SI eosinophils of GF mice exhibited more cytoplasmic protrusions and less granule content than SPF controls; this was consistent with the lower EPO levels detected in intestinal homogenates from GF mice. Lastly, we generated a novel strain of eosinophil-deficient ( $\triangle$ dblGATA1) mice on a GF background. In this system, the absence of eosinophils was associated with increased collagen accumulation in the submucosa as well as reduced allergic sensitization. This study illustrates a novel role for the microbiota in regulating mucosal eosinophils and tissue homoeostasis.

\section{MATERIALS AND METHODS}

\section{Mice and Colonization Procedures}

Age-, vendor-, and strain-matched controls were used in all the experiments. $\mathrm{C} 57 \mathrm{BL} / 6$ and $\mathrm{BALB} / \mathrm{c}$ mice were obtained from Charles River. $\triangle$ dblGATA1 (GATA) mice were bred in house. A novel strain of GF GATA mice was generated by two-cell embryo transfer, as previously described (22). Mice were bred and maintained in flexible film isolators in McMaster's Axenic Gnotobiotic Unit. GF status was monitored weekly by DNA immunofluorescence (SYTOX Green), as well as anaerobic and aerobic culture of cecal stool samples. Mice had unlimited access to autoclaved food and water. ASF-colonized mice were originally generated by co-housing female colonizers harboring ASF, with GF mice. ASF-colonized mice were then bred for 3 generations in individually ventilated racks within the Axenic Gnotobiotic Unit (23). Pathogen contamination and microbiota diversification were evaluated in mouse fecal contents every 2 weeks in sentinels by PCR for Helicobacter bilis, H. ganmani,
$H$. hepaticus, $H$. mastomyrinus, $H$. rodentium, Helicobacter spp., H. typhlonius, and Pneumocystis murina. Mouse serum was also tested for murine viral pathogens by multiplexed fluorometric immunoassay/enzyme-linked immunosorbent assay (ELISA)/indirect fluorescent antibody tests (23). SPF colonization was performed by co-habitation of GF mice with SPF mice for a minimum of 1 month. In some experiments, mice were fed an elemental diet based on amino acids (TD1084 and TD 130916; Harlan Laboratories Inc.) for 3 generations prior to use. Euthanasia was performed under anesthesia by cervical dislocation. All procedures were approved by the McMaster University Animal Research Ethics Board.

\section{Intestinal Cell Isolation}

As previously described $(24,25)$, after flushing intestinal contents with cold PBS, fat was removed, and intestines were opened longitudinally and cut into $\sim 3-5 \mathrm{~mm}$ pieces. Mucus was eliminated by washing with phosphate-buffered saline (PBS) containing $10 \mathrm{mM}$ HEPES and $4 \mu \mathrm{M}$ dithiothreitol (DTT) (Sigma) for $15 \mathrm{~min}$ at $37^{\circ} \mathrm{C}$ while on a shaker. Epithelial cells were removed by 3 rounds of $10 \mathrm{~min}$-washes at $37^{\circ} \mathrm{C}$, under shaking, in PBS containing 10\% fetal bovine serum (FBS), $10 \mathrm{mM}$ HEPES and $5 \mathrm{mM}$ ethylenediaminetetraacetic acid (EDTA). The tissues were then digested in $0.125 \mathrm{U} / \mathrm{mL}$ Collagenase A (Roche) with $130 \mathrm{U} / \mathrm{mL}$ DNase I (Roche) in 10\% FBS containing RPMI for $50-60 \mathrm{~min}$ in a shaker at $37^{\circ} \mathrm{C}$. Lastly, the digested tissues were pressed through a $40 \mu \mathrm{m}$ nylon strainer (Falcon) and immune cells were purified via 40/70\% Percoll (GE Healthcare) gradient and centrifugation.

\section{Tissue Processing and Cell Isolation}

Bone marrow (6), spleen (26), uterus (27), vaginal tract (27), lung (28), and blood (6) were collected and processed as previously described.

\section{EPO Assay}

Intestinal tissue was made up to $100 \mathrm{mg} / \mathrm{mL}$, w/v suspension, in PBS containing complete protease inhibitors (Roche) and rotor-stator homogenized (Polytron; Kinematica, Lucerne, Switzerland). The intestinal homogenate was centrifuged $\left(1952 \mathrm{~g} \times 10 \mathrm{~min}, 4^{\circ} \mathrm{C}\right)$ and the pellet was resuspended in $2 \mathrm{~mL}$ of $0.2 \% \mathrm{NaCl}$ for $30 \mathrm{~s}$ followed by $2 \mathrm{~mL}$ of $1.6 \%$ $\mathrm{NaCl}$ before centrifugation and resuspension at $100 \mathrm{mg} / \mathrm{mL}$ in Hank's balanced salt solution (HBSS) containing $0.5 \%$ hexadecyltrimethylammonium bromide (HTAB) (Sigma: H5882). Pellets were homogenized and freeze/thawed 3 times using liquid nitrogen. Finally, samples were centrifugated, the supernatants were transferred to clean tubes and EPO activity was measured as previously described (29).

\section{Cytokine and Chemokine Array}

Intestinal homogenates were prepared as described (30) with minor modifications: small intestinal samples were homogenized with $20 \mathrm{~mL} / \mathrm{g}$ of buffer (T-Per Tissue Protein Extraction Reagent, Thermo Scientific) containing protease inhibitors (Sigma). Samples were then centrifuged for $30 \mathrm{~min}$ and protein concentration was measured using the DC Protein 
Assay according to standardized protocols (Bio-Rad). Protein concentration in supernatants was normalized to $1 \mathrm{mg} / \mathrm{mL}$ and frozen at $-80^{\circ} \mathrm{C}$ until assay. Cytokine and chemokine levels were determined via a cytokine 44-plex discovery assay (MD44) and a high-sensitivity 18-plex discovery assay (MDHSTC18) performed by Eve Technologies (Calgary, AB). To visualize broad differences in the metabolite signals, raw values were converted to a log scale. The fold change in protein levels between GF and SPF mice was represented on a heatmap with $\mathrm{R}$ software using the heatmap package. Data analysis of cycle threshold values was conducted using the Relative Expression Software Tool-384 (REST-384) version 1.

\section{Flow Cytometry}

Antibodies were obtained from eBioscience, BD Biosciences, or BioLegend. In all assays, cells were incubated with anti-Fc $\gamma$ RII/III before incubation with fluorochrome-conjugated antibodies. Dead cells were excluded by propidium iodide uptake (Sigma) or fixable viability dye eFluor780 (eBioscience) and gated on singlets. On average, a minimum of 300,000 live and singlet cells were analyzed. Fluorescence minus one (FMO) and isotype controls were used for gating. Data were acquired on an LSR II or Fortessa (BD) and analyzed using FlowJo (Treestar). Flowsorting experiments were performed on a FACS ARIA III (BD).

\section{Food Allergy Model}

Peanut butter ( $3.75 \mathrm{mg} ; 1 \mathrm{mg}$ of protein; Kraft, Northfield, IL) with $10 \mu \mathrm{g}$ of cholera toxin (List Biologicals, Campbell, CA) in $0.5 \mathrm{~mL}$ of PBS was administered intragastrically (Delvo SA, Biel, Switzerland) weekly for 4 weeks. Serum was collected by retroorbital bleeding and analyzed for peanut-specific Igs via sandwich ELISA (31-33).

\section{Histology}

Intestinal segments were collected and fixed in $10 \%$ formalin for $24 \mathrm{~h}$, and then washed with $70 \%$ ethanol and paraffin embedded. Sections were stained with the Protocol Hema 3 stain set (Fisher Scientific, Hampton, NH) and Masson's Trichome method $(34,35)$. For image analysis of histological sections, Masson's trichrome stained tissue slides were scanned (VS120-ASW v2.9 slide scanner, with UPlanSApo 20x objective, Olympus) and analyzed using HALO ${ }^{\circledR}$ Image Analysis Platform (v2.2.1870.34, Indica Labs Inc, Corrales, New Mexico) using Area Quantification module (v1.0).

\section{Transmission Electron Microscopy}

Immediately after excision, tissues were immersed in fixative consisting of $3 \%$ formaldehyde and $1 \%$ glutaraldehyde in $0.1 \mathrm{M}$ phosphate buffer ( $\mathrm{pH}$ 7.2). After the initial fixation, samples were post-fixed in $1 \%$ osmium tetroxide for $1 \mathrm{~h}$, dehydrated in graded acetone solutions, and embedded in Polybed 812 (Polysciences, Inc.). Ultrathin sections (60-80 nm) were cut on an LKB MK III ultratome and routinely contrasted with uranyl acetate and lead citrate. The sections were examined using a FEI Tecnai Spirit BioTWIN transmission electron microscope (Fei) (6). Eosinophil circularity was calculated as $4 \Pi$ (total cell area/squared cell membrane perimeter); a value of 1.0 indicates a perfect circle.
The granule content was calculated as (cytoplasm area $=$ total cell area - nuclear area) - (the sum of all granule areas).

\section{Statistics}

Data were analyzed and graphed with GraphPad Prism 8 software (GraphPad Software). Continuous data are expressed as means \pm SEMs and were analyzed by using 1-way ANOVA with Bonferroni post hoc tests and unpaired Student's $t$ test. Differences were considered statistically significant at a $P<0.05$ or as indicated.

\section{RESULTS}

\section{The Microbiota Regulates the Frequency of Intestinal Eosinophils}

In order to quantify eosinophil frequency, LP cells from the SI were isolated and evaluated by flow cytometry (6). Consistent with previous reports $(6,36)$, intestinal eosinophils were identified as $\mathrm{CD}_{4} 5^{+} \mathrm{SSC}^{\text {high }}$ Siglec- $\mathrm{F}^{+}$cells and expressed high levels of CD11b (Figure 1A). This putative population of eosinophils was flow-sorted and stained using Hema 3 to validate their identity. The microscopic analysis showed hallmark morphological features (i.e., lobular polymorphic nucleus and eosinophilic granular cytoplasm) of eosinophils $(1,2)$ in $>95 \%$ of the cells (Figure 1B).

Next, we compared eosinophil frequency in the SI of SPF and GF mice. It is known that in GF mice, compared to SPF, the total mass of the SI and the total surface area are decreased, the LP is thinner and less cellular and the cell renewal rate is lower $(18,37-43)$. Therefore, we considered that the most informative analysis would be to focus on the frequency of immune cells. To account for possible differences in strains biased toward Th1 and Th2 immunity (44), both C57BL/6 and BALB/c strains were assessed. The frequency of intestinal eosinophils from total cells in GF mice was $\sim 2$-fold higher than in SPF controls, regardless of the strain (Figure 1C). We then assessed the distribution of eosinophils along the SI tract of GF and SPF mice. Regardless of colonization status, eosinophils were enriched predominantly in the proximal end of the SI (duodenum) and reduced in the distal end (ileum) (Figure 1D). Nevertheless, within all sections of the SI, GF mice harbored a greater proportion of eosinophils than SPF control mice. These data demonstrate that the microbiota significantly influences the basal tissue eosinophilia of the SI LP.

\section{The Microbiota Sets the Basal Eosinophilic Tone in Naturally Colonized Mucosal Surfaces}

To test whether the differences in eosinophils between GF and SPF mice were directly related to the microbiota, we colonized GF mice with either a complex (SPF) or simple (ASF) microflora (23). To this end, we co-housed separate groups of GF mice with either ASF or SPF mice. The data show that the eosinophilia seen in the SI of GF mice was partially attenuated by colonization with a minimal assortment of only 8 well-defined bacterial species (23) using ASF mice. Eosinophilia was fully attenuated with complex colonization using SPF flora (Figure 2A). These data show a 

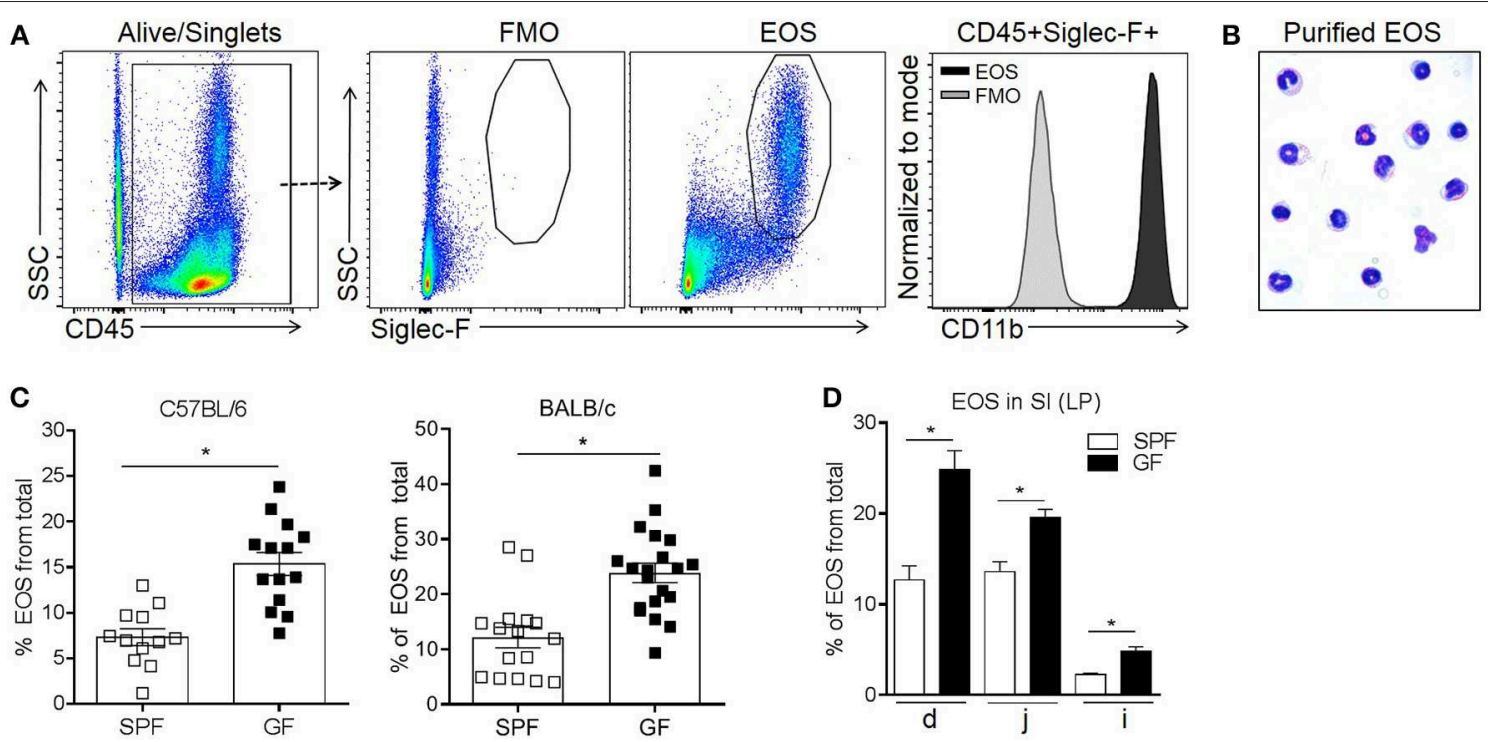

FIGURE 1 | Flow cytometric identification of small intestinal eosinophils (EOS) as live singlet CD45+Siglec-F+ cells (A), morphologic validation (B) and assessment of their frequency in the small intestine (SI) of SPF and GF C57BL/6 and BALB/c mice (C,D). The frequency of EOS from total cells in the lamina propria (LP) of different sections of the SI including duodenum (d), jejunum (j) and ileum (i) of C57BL/6 mice (D). Pooled data from 3 to 4 experiments $(n=12-20)$ (C) or representative data from 3 experiments (D) represented as mean $\pm \mathrm{SEM},{ }^{\star} P<0.05$.
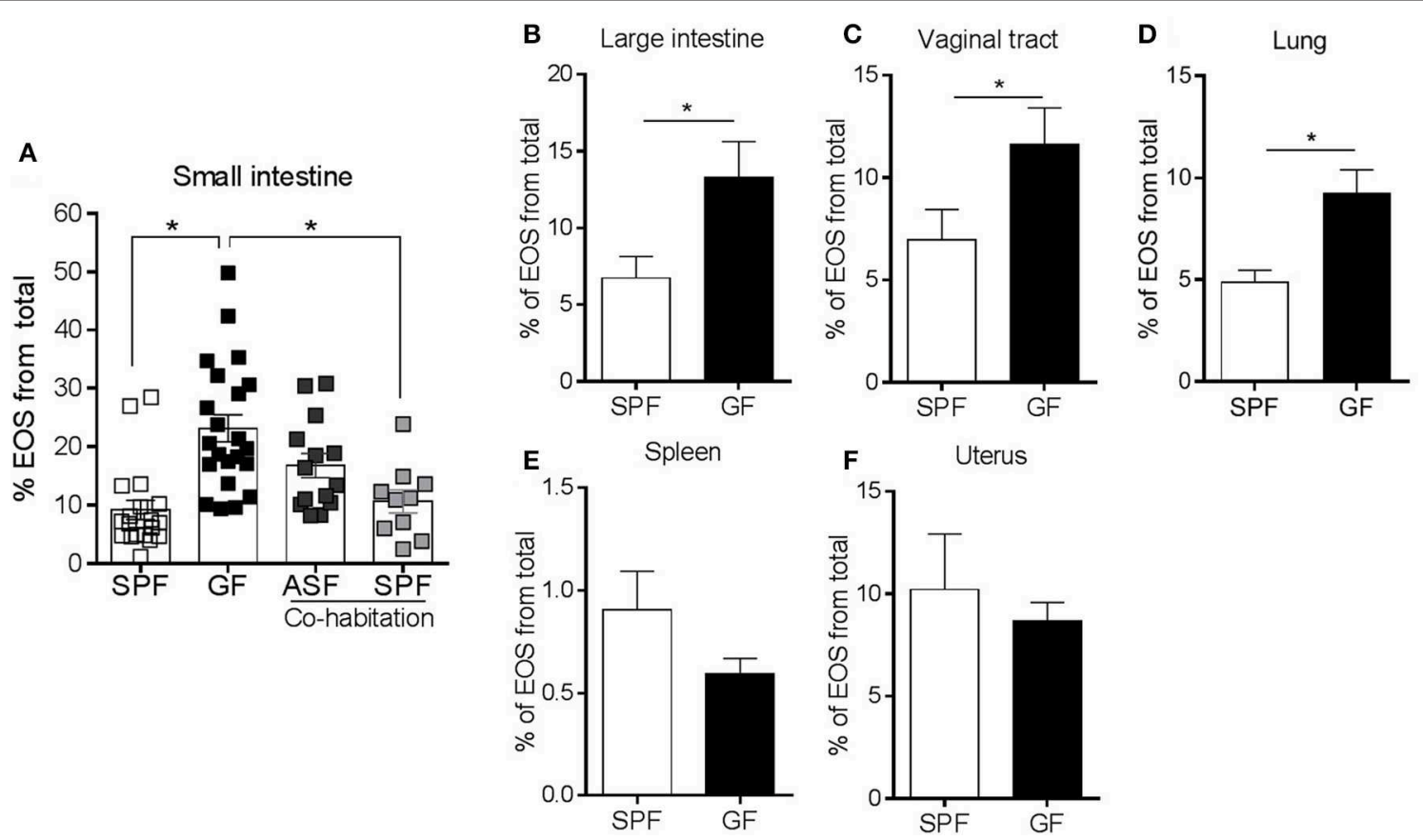

FIGURE 2 | Separate groups of GF mice were colonized by co-habitation with ASF or SPF mice and the presence of small intestinal eosinophils (EOS) was assessed (A). Assessment of EOS frequency in the large intestine, vaginal tract, lung, spleen and uterus of SPF and GF mice by flow cytometry (B-F). Pooled data from 2 to 5 experiments $(n=8-22)$ represented as mean \pm SEM, ${ }^{*} P<0.05$.

graded regulatory relationship between the complexity of the microbiota and tissue eosinophil levels.

Since the microbiota regulated the frequency of enteric eosinophils, we next examined whether GF induced eosinophilia was present in other naturally colonized mucosal sites (large intestine, vaginal tract and lung), sterile -or poorly colonized- mucosal sites (uterus) (45) and non-mucosal sites (spleen). The frequency of eosinophils was also 
significantly higher in the large intestine, vaginal tract and lung of GF mice compared to SPF (Figures 2B-D) but not in sterile tissues such as the spleen (Figure 2E) and uterus (Figure 2F). These data further support the concept that the frequency of tissue eosinophils is dependent on the natural colonization status.

\section{The Maturity of the Immune System Is Not Associated With Intestinal Eosinophilia}

It is well-established that the adaptive immune system of GF mice is immature, particularly as it refers to $\mathrm{T}$ cells (18). Consistent with previous observations $(46,47)$, we found that the frequency of $\mathrm{CD}^{+} \mathrm{T}$ cells was significantly lower in the SI of GF mice compared to SPF controls (Figure 3A). In contrast, there were no statistically significant differences in the frequency of B cells, dendritic cells (DCs), macrophages and mast cells (Figure 3A). To investigate whether the eosinophilia observed in GF conditions was due to the absence of colonization or inherent to an immature immune system, we generated microbiotacompetent mice with an immature immune system (48). To this end, BALB/c mice, fed with an elemental (amino acid) diet and housed in a SPF environment, were bred for 3 generations. Fewer Peyer's patches and a lower frequency of $\mathrm{CD} 4^{+} \mathrm{T}$ cells were observed in the LP, thus confirming the immaturity of the adaptive immune system of these mice (Figure 3B). We did not find changes in the frequency of B cells, macrophages or eosinophils. These findings indicate that the relative eosinophilia in GF mice is likely due to a lack of microbial-derived signals rather than immune immaturity per se.

\section{The Microbiota Regulates Eosinophil Attraction and Retention Signals in Mucosal Tissues}

Tissue accumulation of eosinophils associated with chronic intestinal inflammation is typically attributed to increased eosinopoiesis (49). Here, we investigated whether the same mechanism applies to constitutive eosinophilia in healthy GF mice. We found that there were no differences in BM eosinophils between GF and SPF mice, nor were differences in EOS circulating in the peripheral blood (data not shown). This suggested that eosinophil accumulation in mucosal sites of otherwise healthy GF mice might be mediated by increased expression of attraction and/or retention signals in the SI, large intestine, lung, and vaginal tract.

To identify signals associated with eosinophil migration and retention at the tissue level, we analyzed chemokine and cytokine levels in the proximal (duodenum) and distal (ileum) SI segments of GF and SPF mice (Figure 4A). Overall, cytokine and chemokine production was lower in the SI of GF mice as compared to SPF; this is consistent with the underdeveloped mucosal immune system reported in GF mice (18). Nevertheless, compared to SPF controls, GF mice exhibited a significant increase in IL-3 (50) and $\operatorname{VEGF}(51,52)$, which are associated with eosinophil chemotaxis and survival (Figure 4B). Furthermore, we observed a significant decrease in the levels of IL-11 (53) and CXCL9 (54) in GF mice, which regulate eosinophil recruitment (Figure 4B). These data suggest that the microbiota regulates signals involved in the attraction, retention and survival of eosinophils in the SI, the absence
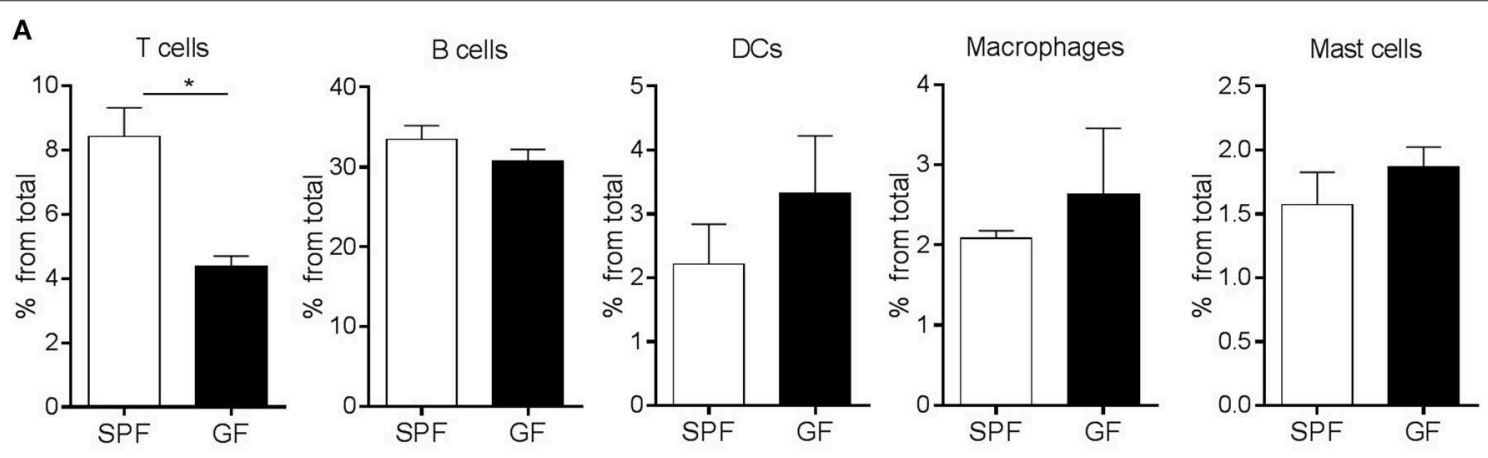

B Peyer's patches
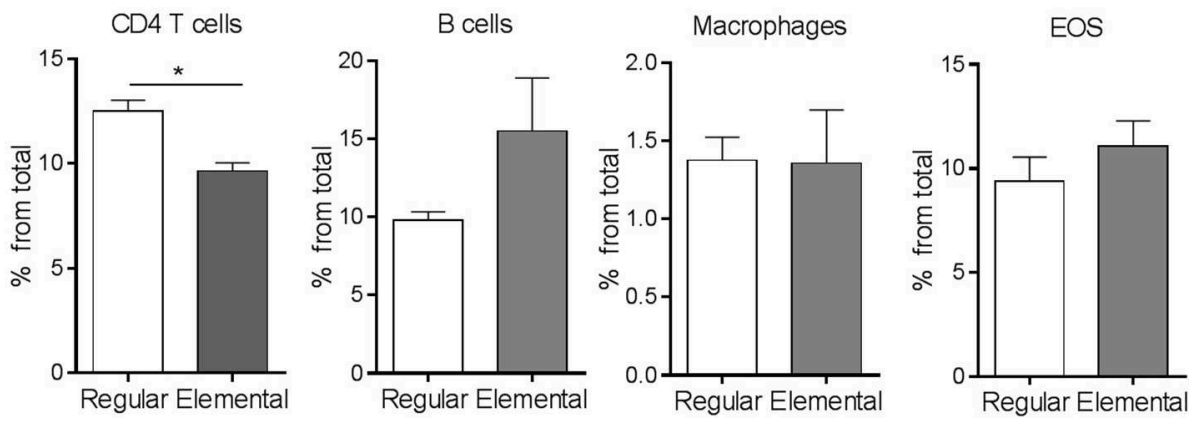

FIGURE 3 | Flow cytometric characterization of adaptive and innate immune compartments (A,B) in the small intestine of GF and SPF mice fed a regular (A) or elemental diet (B). Pooled data from 2 to 4 experiments $(n=6-22)$ represented as mean \pm SEM, ${ }^{*} P<0.05$. 
A

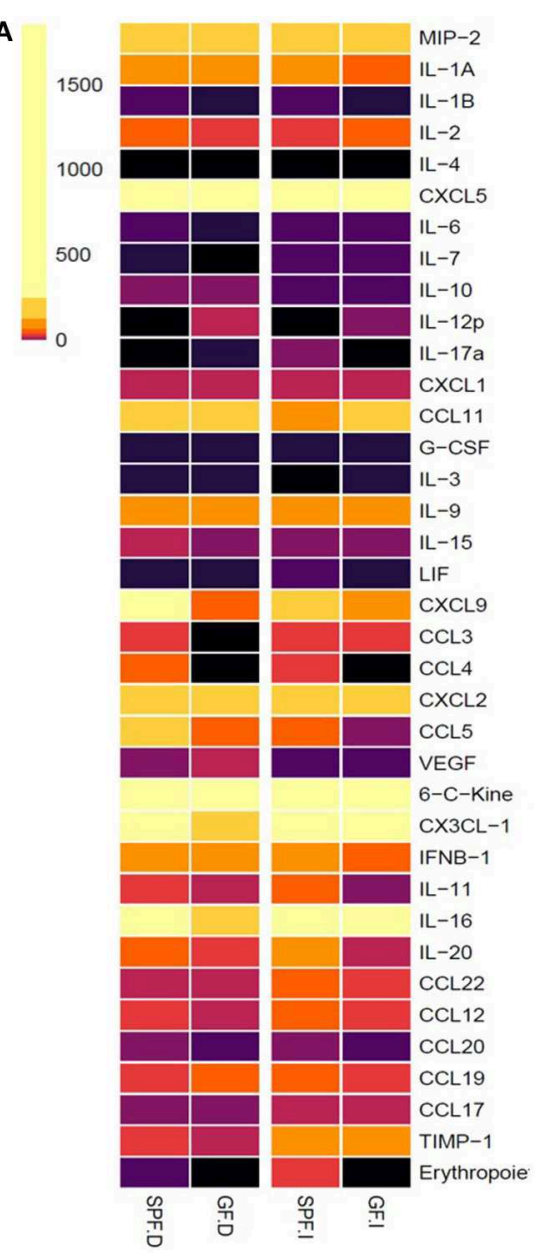

B

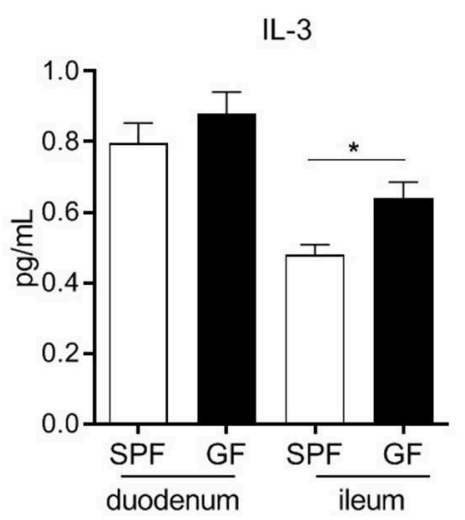

IL-11

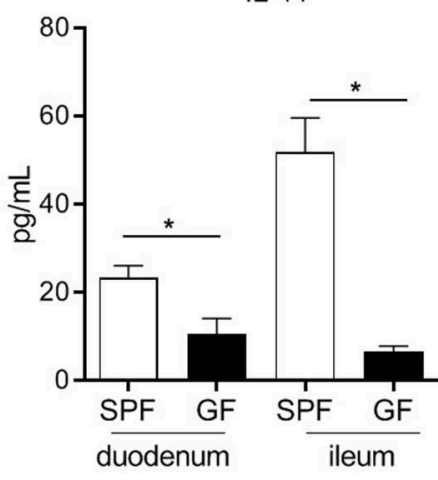

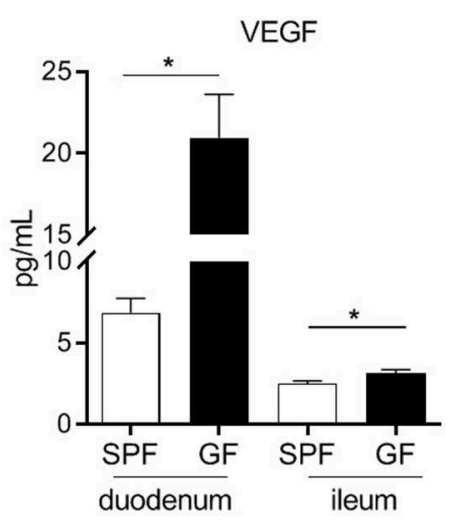

CXCL9

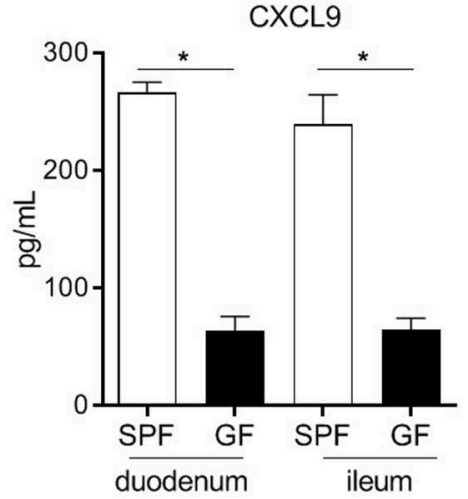

FIGURE 4 | Heatmap of chemokine and cytokine protein levels in proximal (duodenum; D) and distal (ileum; I) small intestinal homogenates from GF and SPF mice as determined by protein array (A). Relevant proteins differentially produced both in the proximal and distal small intestine of SPF and GF mice (B). Data from 6 mice $(\mathbf{A}, \mathbf{B})$ represented as mean $\pm \mathrm{SEM},{ }^{\star} P<0.05$.

of which results in the relative eosinophilia found in GF conditions (50).

\section{Eosinophil Morphology and Functionality Are Influenced by the Microbiota}

In order to evaluate eosinophil function in GF mice, we performed comprehensive transmission electron microscopy analysis of small intestinal sections from GF and SPF mice (Figures 5A-D). Eosinophils in GF mice (Figures 5B-D) exhibited profound morphological alterations in comparison to SPF controls (Figure 5A). Eosinophils from GF mice had significantly more cytoplasmic protrusions; this was quantified and measured as reduced circularity of the outer membrane perimeter (Figure 5E). Signs of eosinophil cytoplasmic lysis (ECL), potentially associated with the cytoplasmic protrusions, were found, although very rarely, in eosinophils from GF mice (Figure 5D). While increased cytoplasmic protrusions are indicative of cell activation, we did not find evidence of eosinophil degranulation in either of them. Strikingly, intestinal eosinophils from GF mice had significantly less granule content (Figure 5F) and granules of smaller size than SPF counterparts. To substantiate these findings, the degranulation status of eosinophils was also determined by quantifying EPO activity (29, 55 ) in SI homogenates of GF and SPF mice. Despite the extensive eosinophilia (Figure 1C), significantly lower EPO activity was detected in GF mice (Figure 5G) compared to SPF controls.

\section{The Microbiota Modulates}

\section{Eosinophil-Mediated Intestinal Remodeling and Allergic Sensitization}

To investigate the functional significance of the morphological features observed in GF mice, we generated a novel eosinophildeficient mouse strain ( $\triangle$ dblGATA; GF-GATA) on a GF background. Given that eosinophils are known to contribute to tissue remodeling, intestinal tissues were assessed with Masson's Trichome staining $(34,35)$ to evaluate collagen deposition (Figure 6A). To remove potential bias of field selection, these differences were quantified using the HALO 

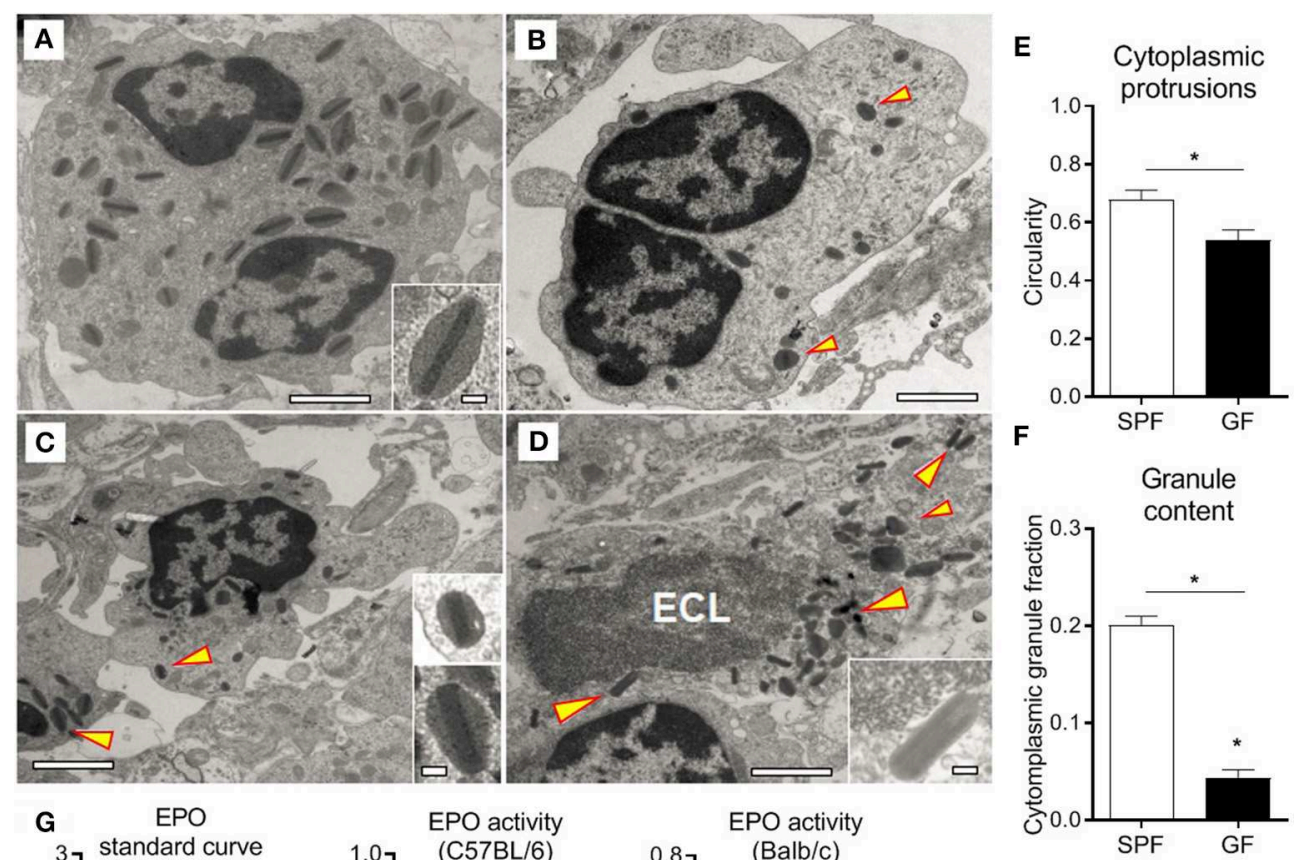
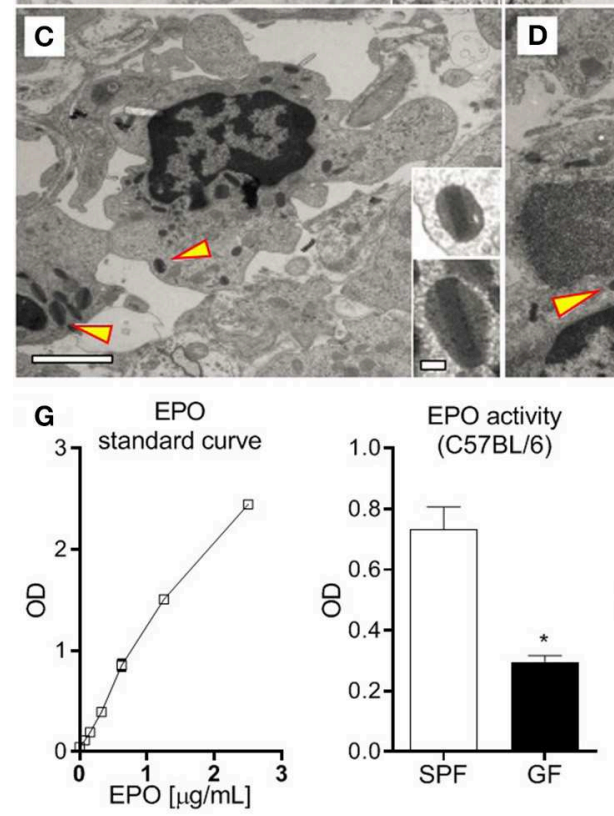

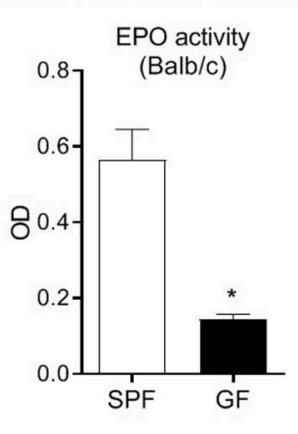

FIGURE 5 | Normal SI eosinophils transmission electron microscopy ultrastructure (A), showing bi-lobed nuclei and a high density of granules composed of an electron-dense core surrounded by an electron-lucent matrix rich in EPO (arrowhead). SI eosinophils from GF mice (B-D) exhibit cytoplasmic protrusions, measured as reduced circularity (E), lower content of cytoplasmic granules (F) and, occasionally, ECL signs (D). Assessment of EPO in intestinal homogenates of SPF and GF mice (G). Representative (A-D) and pooled (E,F) data from 6 mice, and pooled data from 2 independent experiments $(n=6)(\mathbf{G})$ represented as mean \pm SEM, ${ }^{\star} P<0.05$.

Image Analysis software. This analysis demonstrated higher collagen density in the submucosal layers of eosinophil-deficient mice, particularly in GF conditions, as compared to SPF controls (Figure 6B). These findings suggest that the absence of eosinophils in GF GATA mice is associated with increased fibrotic tissue remodeling.

Intestinal eosinophils play a critical role in the initiation of allergic responses to food allergens. We have previously demonstrated that eosinophil-deficient ( $\Delta$ dblGATA) mice are unable to produce peanut-specific immunoglobulins (6). Additionally, gut dysbiosis has been associated with a higher risk of developing allergy in humans (56-59), and GF mice have been shown to be prone to generate Th2 responses $(60,61)$. In this context, we evaluated if the lack of microbial modulation of eosinophils may impact allergic sensitization to foods. We employed an established food allergy model using intragastric sensitization to peanut $(24,32,62,63)$ in GF mice on a GATA or $\mathrm{C} 57 \mathrm{BL} / 6$ backgrounds. In agreement with previous studies (61), GF mice generated higher levels of peanut-specific IgE and IgG1 than SPF controls (Supplementary Figure 1). However, the production of both immunoglobulins was significantly lower in GF mice deficient in eosinophils as compared to GF controls (Figures 6C,D). These findings raise the possibility that the microbiota influences the development of food allergic sensitization partly through its effects on intestinal eosinophils.

\section{DISCUSSION}

Mucosal eosinophils have been traditionally considered recruited proinflammatory cells, whose biological benefit is limited to defense against parasitic infections. However, new evidence has established that eosinophils also contribute to the initiation, propagation, and resolution of innate and adaptive immune responses, and to homeostatic tissue repair and remodeling (4, 5, $64,65)$. The diversity of functions ascribed to enteric eosinophils in particular has propelled investigation into the mechanisms that influence their tissue residence and functionality. In this regard, the microbiota is known to be critical for the development of the SI mucosal adaptive immune system (18). Given that eosinophils natively inhabit the SI (66), we investigated the 


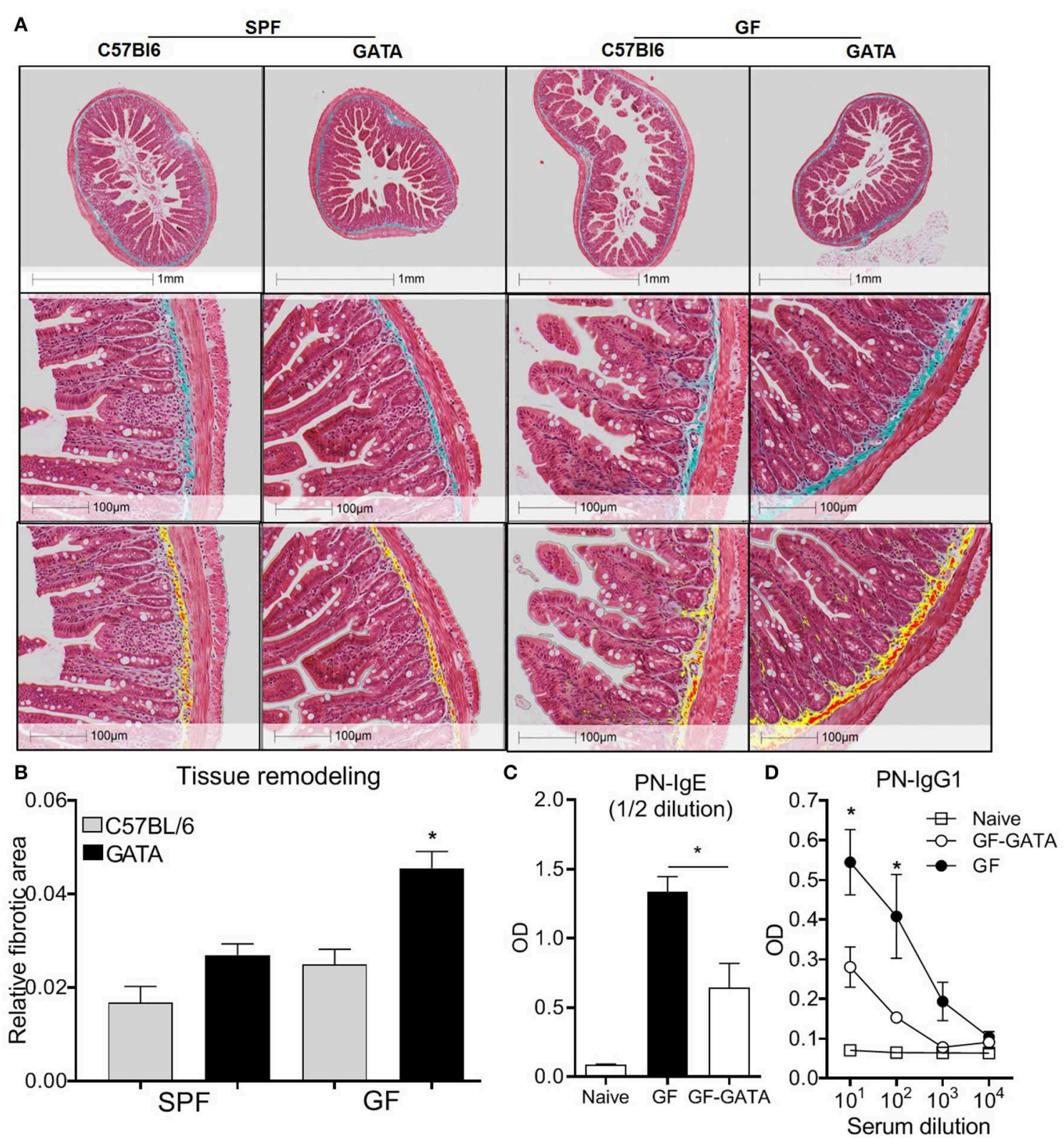

FIGURE 6 | Representative histological examples of intestinal fibrosis (A, upper panels) and associated Halo quantification of fibrotic surface on digitalized (20X) sections where yellow and red represents Masson's Trichrome positive stain (A, lower panels) and associated quantification (B) of overall fibrotic area performed on GF mice, eosinophil deficient GF mice (GATA-GF) and controls. GF mice, eosinophil deficient GF mice (GATA-GF) and controls were intragastrically sensitized to peanut $(\mathrm{PN})$ and serum levels of PN-specific $\lg$ E (C) and lgG1 (D) were determined by ELISA. Data from 4 to 5 mice $\mathbf{( A , B )}$ or pooled data from 2 experiments $(n=6)(\mathbf{C}, \mathbf{D})$ represented as mean \pm SEM, ${ }^{\star} P<0.05$.

impact of the microbiota on intestinal eosinophil frequency and function.

Comprehensive quantification of intestinal eosinophils was carried out by flow cytometry $(6,36)$ and further validated by morphological analysis (Figures 1A,B). The total frequency of intestinal eosinophils in either C57BL6 or BALB/c was $\sim 2$ fold higher in GF mice as compared to SPF controls (Figure 1C). This is in contrast with the findings by Mishra et al. (67), who did not observe significant differences in eosinophils numbers in the GI of SPF and GF mice when quantified by histology. Several factors might have contributed to this discrepancy including the strain of mice (Black Swiss mice vs. C57BL/6 and BALB/c), microbiome differences under SPF conditions, the number of mice utilized in each study ( $n=5$ vs. $n=12-20$ ) and, lastly, the technique employed for eosinophils quantification, as it is likely that flow cytometry allowed for a more comprehensive and precise quantification than immunohistochemistry using the eosinophil granule protein, major basic protein (MBP) (68). Importantly, we show that intestinal eosinophils in GF mice contain granules of smaller size and less cytoplasmic granule content than SPF 
controls, which may lead to eosinophil underdetection when using MBP-based methods.

Consistent with previous reports $(6,67)$, eosinophils were pre-eminently localized in the proximal end of the SI and decreased in frequency distally. However, the proportion of eosinophils in each section was significantly higher in GF mice compared to SPF controls (Figure 1D). Importantly, colonization of GF mice with a complex microbiota reduced enteric eosinophils to a frequency comparable to that in SPF mice. This shows that enteric eosinophilia is greatly influenced by the host intestinal microbiome, and that this effect is, to some extent, dependant on the composition of the bacterial community (Figure 1E).

We next considered whether enteric eosinophilia could be an innate response to compensate for the immaturity of the adaptive immune system that occurs in GF mice. It is known that feeding SPF mice with an elemental diet results in an immature immune system (69). These mice also exhibit an intestinal architecture similar to GF mice (i.e., extended villi, loss of the typical pleated appearance, small Peyer's patches, etc.) (48). Our data show that the administration of an elemental diet for 3 generations resulted in features indicative of immune immaturity, such as a reduced number of Peyer's patches and lower $\mathrm{CD}^{+} \mathrm{T}$ lymphocytes. However, it did not lead to the eosinophilia identified in GF mice fed with a conventional diet (Figure 2), which suggests that enteric eosinophilia is independent of the maturity of the adaptive immune system and thus dependent on the microbiota.

The relative eosinophilia observed in GF mice, its regulation by complex microbial colonization and its independence of the maturity of the adaptive immune system, along with the findings of unperturbed eosinopoiesis suggest that the microbiota directly regulates enteric eosinophils through interactions with cells resident in the mucosal compartment. The significant changes in the production of signals [IL-3 (50), VEGF (51, 52), IL11 (53) and CXCL9 (54)] that regulate eosinophil migration, attraction and survival of eosinophils in the SI of GF mice supports this notion (Figure 4B). The decreased levels of CXCL9 in GF mice are particularly relevant. CXCL9 is an inhibitory eosinophil migration and activation pathway that acts via CCR3, the major eosinophil chemokine receptor, which binds eotaxins. For example, a low dose of CXCL9 $(1 \mu \mathrm{g} /$ mouse) was reported to block around $90 \%$ of pulmonary eosinophilia induced by eotaxin-2 (70). Therefore, this natural restrainer of eosinophil migration and activation is impaired under GF conditions.

The formation of cytoplasmic protrusions might relate with a migratory stage and is indicative of cell activation; despite their abundance in eosinophils from GF mice (Figure 5E), there were no signs of degranulation. In fact, EPO levels were lower in the SI of GF mice as compared to SPF (Figure 5G), consistent with the smaller content and size of cytoplasmic granules shown by transmission electron microscopy (Figure 5F). The drastic morphological changes observed in eosinophils from GF mice, as compared to SPF, evidence that aspects related to granule processing and maturation, as well as functionality, are influenced by the microbiota. If this process is mediated by direct interactions of microbiota, or microbial metabolites, with eosinophils, or via a third party, needs to be elucidated. For example, it has been recently reported that Peyer's patch dendritic cells detect mucosal-resident bacteria via the Mincle-Syk axis, which control intestinal immune barrier function (71).

Eosinophil activation is often associated with tissue damage but eosinophils also participate in tissue homeostasiss (72). Increased eosinophil activation has been detected in patients with ulcerative colitis (UC), as compared to controls. Interestingly, the number of activated eosinophils was shown to be greater during the remission phase of UC (73), which may suggest a dual role in intestinal inflammation and repair. We found that in mice lacking both eosinophils and microbiota, collagen deposition in the submucosal layer was double to that of mice deficient in either eosinophils or microbiota alone (Figures 6A,B), suggesting that at least certain components of tissue remodeling are regulated by interactions between the microbiota and eosinophils.

Several lines of evidence have indicated that dysbiosis in humans is associated with an increased prevalence of allergic sensitization $(56,58,74-76)$. However, the mechanisms underlying this association remain to be fully elucidated. It was recently shown that GF and antibiotic-treated mice developed increased allergic sensitization as compared to SPF mice (61). Moreover, Clostridia colonization was shown to induce IL22 production by ROR- $\gamma \mathrm{t}^{+}$ILCs and $\mathrm{T}$ cells, which reduced intestinal permeability and systemic access of the allergen (61). In addition, it has been recently reported that certain bacterial species such as Clostridiales suppressed food allergy in mice via induction of $\mathrm{ROR}-\gamma \mathrm{t}^{+}$regulatory $\mathrm{T}$ cells in a MyD88-dependent manner (77). Given that we have shown that enteric eosinophils are essential to the induction of allergic sensitization in SPF mice (6), these observations raise the question of whether the microbiota and enteric eosinophils synergize in the induction of allergic sensitization. Here, having demonstrated that GF mice exhibit heightened eosinophilia, we show that the absence of eosinophils in GF mice results in an attenuation of allergic sensitization. Thus, these data support the concept that the microbiota influences the capacity to develop allergic sensitization, at least in part, through its effects on enteric eosinophils.

In summary, this study demonstrates that eosinophil frequency and activation in the intestinal mucosa is regulated by the microbiota. It also shows that processes such as tissue repair and the induction of allergic sensitization appear to be regulated by an interplay between the commensal microbiota and intestinal eosinophils. Given that the tissue microenvironment crucially shapes the nature and evolution of subsequent antigen-host interactions, these data have fundamental implications to understanding the role of the microbiota and eosinophils in health and disease.

\section{DATA AVAILABILITY STATEMENT}

All datasets generated for this study are included in the article/Supplementary Material.

\section{ETHICS STATEMENT}

The animal study was reviewed and approved by McMaster University Animal Research Ethics Board. 


\section{AUTHOR CONTRIBUTIONS}

RJ-S conceptualized the project and designed experiments. RJ-S and VA performed experiments, analyzed the data, and wrote the manuscript. TW, MG, TM, RC, JK, YE, and AH helped with experiments. HG conducted experiments in the Axenic and Gnotobiotic Unit. EV generated GATA-GF mice. SA and KA performed HALO analysis. JE conducted EM analysis. EV, KA, and DC provided scientific input and revised the manuscript. MJ obtained funding, oversaw the project, and edited the manuscript.

\section{FUNDING}

This work was supported by Food Allergy Canada, the Delaney family, the Zych family, the Walter and Maria Schroeder

\section{REFERENCES}

1. Lee JJ, Jacobsen EA, McGarry MP, Schleimer RP, Lee NA. Eosinophils in health and disease: the LIAR hypothesis. Clin Exp Allergy. (2010) 40:563-75. doi: 10.1111/j.1365-2222.2010.03484.x

2. Rosenberg HF, Dyer KD, Foster PS. Eosinophils: changing perspectives in health and disease. Nat Rev Immunol. (2013) 13:9-22. doi: 10.1038/ nri3341

3. Arnold IC, Artola-Boran M, Tallon de Lara P, Kyburz A, Taube C, Ottemann K, et al. Eosinophils suppress Th1 responses and restrict bacterially induced gastrointestinal inflammation. J Exp Med. (2018) 215:2055-72. doi: $10.1084 /$ jem.20172049

4. Abdala-Valencia H, Coden ME, Chiarella SE, Jacobsen EA, Bochner BS, Lee JJ, et al. Shaping eosinophil identity in the tissue contexts of development, homeostasis, and disease. J Leukoc Biol. (2018) 104:95-108. doi: 10.1002/JLB.1MR1117-442RR

5. Xenakis JJ, Howard ED, Smith KM, Olbrich CL, Huang Y, Anketell D, et al. Resident intestinal eosinophils constitutively express antigen presentation markers and include two phenotypically distinct subsets of eosinophils. Immunology. (2018) 154:298-308. doi: 10.1111/imm.12885

6. Chu DK, Jimenez-Saiz R, Verschoor CP, Walker TD, Goncharova S, LlopGuevara A, et al. Indigenous enteric eosinophils control DCs to initiate a primary Th2 immune response in vivo. J Exp Med. (2014) 211:1657-72. doi: $10.1084 /$ jem. 20131800

7. Canas JA, Sastre B, Rodrigo-Munoz JM, Fernandez-Nieto M, Barranco $\mathrm{P}$, Quirce S, et al. Eosinophil-derived exosomes contribute to asthma remodelling by activating structural lung cells. Clin Exp Allergy. (2018) 48:1173-85. doi: 10.1111/cea.13122

8. Takemura N, Kurashima Y, Mori Y, Okada K, Ogino T, Osawa $\mathrm{H}$, Matsuno $\mathrm{H}$, et al. Eosinophil depletion suppresses radiationinduced small intestinal fibrosis. Sci Transl Med. (2018) 10:eaan0333. doi: 10.1126/scitranslmed.aan0333

9. Bordon Y. Mucosal immunology: eosinophils get the party started. Nat Rev Immunol. (2014) 14:580-1. doi: 10.1038/nri3731

10. Hogan SP, Waddell A, Fulkerson PC. Eosinophils in infection and intestinal immunity. Curr Opin Gastroenterol. (2013) 29:7-14. doi: 10.1097/ MOG.0b013e32835ab29a

11. Filippone RT, Sahakian L, Apostolopoulos V, Nurgali K. Eosinophils in inflammatory bowel disease. Inflammatory Bowel Dis. (2019) 25:1140-51. doi: 10.1093/ibd/izz024

12. Yang BG, Seoh JY, Jang MH. Regulatory eosinophils in inflammation and metabolic disorders. Immune Netw. (2017) 17:41-7. doi: 10.4110/ in.2017.17.1.41

13. Sugawara R, Lee EJ, Jang MS, Jeun EJ, Hong CP, Kim JH, et al. Small intestinal eosinophils regulate Th17 cells by producing IL-1 receptor
Foundation and AllerGen NCE. EV holds a Canada Research Chair and is funded by CIHR grant MOP\# 142773.

\section{ACKNOWLEDGMENTS}

We acknowledge Dr. Puja Bagri for critical review of the manuscript. We thank all the members of the Jordana Lab for technical help and scientific input. This manuscript has been released as a Pre-Print at bioRxiv (78).

\section{SUPPLEMENTARY MATERIAL}

The Supplementary Material for this article can be found online at: https://www.frontiersin.org/articles/10.3389/fimmu. 2020.00155/full\#supplementary-material antagonist. J Exp Med. (2016) 213:555-67. doi: 10.1084/jem.2014 1388

14. Matsumoto K, Fukuda S, Nakamura Y, Saito H. Amphiregulin production by human eosinophils. Int Arch Allergy Immunol. (2009) 149 (Suppl. 1):39-44. doi: $10.1159 / 000210652$

15. Wen T, Rothenberg ME. The regulatory function of eosinophils. Microbiol Spectr. (2016) 4. doi: 10.1128/microbiolspec.MCHD-0020-2015

16. Shi $\mathrm{N}, \mathrm{Li} \mathrm{N}$, Duan $\mathrm{X}$, Niu $\mathrm{H}$. Interaction between the gut microbiome and mucosal immune system. Mil Med Res. (2017) 4:14. doi: 10.1186/s40779-017-0122-9

17. McDermott AJ, Huffnagle GB. The microbiome and regulation of mucosal immunity. Immunology. (2014) 142:24-31. doi: 10.1111/imm.12231

18. Smith K, McCoy KD, Macpherson AJ. Use of axenic animals in studying the adaptation of mammals to their commensal intestinal microbiota. Semin Immunol. (2007) 19:59-69. doi: 10.1016/j.smim.2006.10.002

19. Crabbe PA, Bazin H, Eyssen H, Heremans JF. The normal microbial flora as a major stimulus for proliferation of plasma cells synthesizing IgA in the gut. The germ-free intestinal tract. Int Arch Allergy Appl Immunol. (1968) 34:362-75. doi: 10.1159/000230130

20. Bandeira, Mota-Santos T, Itohara S, Degermann S, Heusser C, Tonegawa S, Coutinho A. Localization of gamma/delta T cells to the intestinal epithelium is independent of normal microbial colonization. J Exp Med. (1990) 172:239-44. doi: $10.1084 /$ jem.172.1.239

21. Rosenberg HF, Masterson JC, Furuta GT. Eosinophils, probiotics, and the microbiome. J Leukoc Biol. (2016) 100:881-8. doi: 10.1189/jlb.3RI0416-202R

22. Slack E, Hapfelmeier S, Stecher B, Velykoredko Y, Stoel M, Lawson MA, et al. Innate and adaptive immunity cooperate flexibly to maintain host-microbiota mutualism. Science. (2009) 325:617-20. doi: 10.1126/science.1172747

23. Galipeau HJ, McCarville JL, Huebener S, Litwin O, Meisel M, Jabri B, et al. Intestinal microbiota modulates gluten-induced immunopathology in humanized mice. Am J Pathol. (2015) 185:2969-82. doi: 10.1016/j.ajpath.2015.07.018

24. Jimenez-Saiz R, Chu DK, Mandur TS, Walker TD, Gordon ME, Chaudhary $\mathrm{R}$, et al. Lifelong memory responses perpetuate humoral TH2 immunity and anaphylaxis in food allergy. J Allergy Clin Immunol. (2017) 140:1604-15 e5. doi: 10.1016/j.jaci.2017.01.018

25. Carlens J, Wahl B, Ballmaier M, Bulfone-Paus S, Forster R, Pabst O. Common gamma-chain-dependent signals confer selective survival of eosinophils in the murine small intestine. J Immunol. (2009) 183:5600-7. doi: 10.4049/jimmunol.0801581

26. Jimenez-Saiz R, Rupa P, Mine Y. Immunomodulatory effects of heated ovomucoid-depleted egg white in a BALB/c mouse model of egg allergy. $J$ Agric Food Chem. (2011) 59:13195-202. doi: 10.1021/jf202963r

27. Anipindi VC, Bagri P, Roth K, Dizzell SE, Nguyen PV, Shaler CR, et al. Estradiol Enhances CD4+ T-cell anti-viral immunity by priming vaginal DCs 
to induce Th17 responses via an IL-1-dependent pathway. PLoS Pathog. (2016) 12:e1005589. doi: 10.1371/journal.ppat.1005589

28. Chu DK, Llop-Guevara A, Walker TD, Flader K, Goncharova S, Boudreau JE, et al. IL-33, but not thymic stromal lymphopoietin or IL-25, is central to mite and peanut allergic sensitization. J Allergy Clin Immunol. (2013) 131:187-200 e1-8. doi: 10.1016/j.jaci.2012.08.002

29. Humbles AA, Conroy DM, Marleau S, Rankin SM, Palframan RT, Proudfoot $\mathrm{AE}$, et al. Kinetics of eotaxin generation and its relationship to eosinophil accumulation in allergic airways disease: analysis in a guinea pig model in vivo. J Exp Med. (1997) 186:601-12. doi: 10.1084/jem.186.4.601

30. Ghia JE, Blennerhassett P, Kumar-Ondiveeran H, Verdu EF, Collins SM. The vagus nerve: a tonic inhibitory influence associated with inflammatory bowel disease in a murine model. Gastroenterology. (2006) 131:1122-30. doi: 10.1053/j.gastro.2006.08.016

31. Swirski FK, Sajic D, Robbins CS, Gajewska BU, Jordana M, Stampfli MR. Chronic exposure to innocuous antigen in sensitized mice leads to suppressed airway eosinophilia that is reversed by granulocyte macrophage colony-stimulating factor. J Immunol. (2002) 169:3499-506. doi: 10.4049/jimmunol.169.7.3499

32. Chu DK, Mohammed-Ali Z, Jimenez-Saiz R, Walker TD, Goncharova S, LlopGuevara A, et al. T helper cell IL-4 drives intestinal Th2 priming to oral peanut antigen, under the control of OX40L and independent of innate-like lymphocytes. Mucosal Immunol. (2014) 7:1395-404. doi: 10.1038/mi.2014.29

33. Jimenez-Saiz R, Ellenbogen Y, Koenig JFE, Gordon ME, Walker TD, Rosace $\mathrm{D}$, et al. IgG1(+) B-cell immunity predates IgE responses in epicutaneous sensitization to foods. Allergy. (2019) 74:165-75. doi: 10.1111/all.13481

34. Goldner J. A modification of the masson trichrome technique for routine laboratory purposes. Am J Pathol. (1938) 14:237-43.

35. Fischer AH, Jacobson KA, Rose J, Zeller R. Hematoxylin and eosin staining of tissue and cell sections. CSH Protoc. (2008) 2008:pdb prot4986. doi: 10.1101/pdb.prot 4986

36. Dyer KD, Garcia-Crespo KE, Killoran KE, Rosenberg HF. Antigen profiles for the quantitative assessment of eosinophils in mouse tissues by flow cytometry. J Immunol Methods. (2011) 369:91-7. doi: 10.1016/j.jim.2011.04.009

37. Levenson SM, Tennant B. Some metabolic and nutritional studies with germfree animals. Fed Proc. (1963) 22:109-19.

38. Gordon HA. Morphological and physiological characterization of germfree life. Ann N Y Acad Sci. (1959) 78:208-20. doi: 10.1111/j.1749-6632.1959.tb53104.x

39. Meslin JC, Sacquet E, Guenet JL. [Action of bacterial flora on the morphology and surface mucus of the small intestine of the rat]. Ann Biol Anim Biochim Biophys. (1973) 13:203-14. doi: 10.1051/rnd:19730207

40. Meslin JC, Sacquet E. Effects of microflora on the dimensions of enterocyte microvilli in the rat. Reprod Nutr Dev. (1984) 24:307-14. doi: 10.1051/rnd:19840309

41. Gordon HA, Bruckner-Kardoss E. Effect of normal microbial flora on intestinal surface area. Am J Physiol. (1961) 201:175-8. doi: 10.1152/ajplegacy.1961.201.1.175

42. Glaister JR. Factors affecting the lymphoid cells in the small intestinal epithelium of the mouse. Int Arch Allergy Appl Immunol. (1973) 45:719-30. doi: $10.1159 / 000231071$

43. Abrams GD, Bauer H, Sprinz H. Influence of the normal flora on mucosal morphology and cellular renewal in the ileum. A comparison of germ-free and conventional mice. Lab Invest. (1963) 12:355-64.

44. Sellers RS, Clifford CB, Treuting PM, Brayton C. Immunological variation between inbred laboratory mouse strains: points to consider in phenotyping genetically immunomodified mice. Vet Pathol. (2012) 49:32-43. doi: 10.1177/0300985811429314

45. Perez-Munoz ME, Arrieta MC, Ramer-Tait AE, Walter J. A critical assessment of the "sterile womb" and "in utero colonization" hypotheses: implications for research on the pioneer infant microbiome. Microbiome. (2017) 5:48. doi: 10.1186/s40168-017-0268-4

46. Macpherson AJ, Harris NL. Interactions between commensal intestinal bacteria and the immune system. Nat Rev Immunol. (2004) 4:478-85. doi: $10.1038 /$ nri1373

47. Round JL, Mazmanian SK. The gut microbiota shapes intestinal immune responses during health and disease. Nat Rev Immunol. (2009) 9:313-23. doi: $10.1038 /$ nri2515
48. Faria AM, Gomes-Santos AC, Goncalves JL, Moreira TG, Medeiros SR, Dourado LP, et al. Food components and the immune system: from tonic agents to allergens. Front Immunol. (2013) 4:102. doi: 10.3389/fimmu.2013.00102

49. Griseri T, Arnold IC, Pearson C, Krausgruber T, Schiering C, Franchini F, et al. Granulocyte macrophage colony-stimulating factor-activated eosinophils promote interleukin-23 driven chronic colitis. Immunity. (2015) 43:187-99. doi: 10.1016/j.immuni.2015.07.008

50. Davoine F, Lacy P. Eosinophil cytokines, chemokines, and growth factors: emerging roles in immunity. Front Immunol. (2014) 5:570. doi: 10.3389/fimmu.2014.00570

51. Feistritzer C, Kaneider NC, Sturn DH, Mosheimer BA, Kahler CM, Wiedermann CJ. Expression and function of the vascular endothelial growth factor receptor FLT-1 in human eosinophils. Am J Respir Cell Mol Biol. (2004) 30:729-35. doi: 10.1165/rcmb.2003-0314OC

52. Cao Q, Zhang T, Zhang J. Correlation analysis of STAT3 and VEGF expression and eosinophil infiltration in nasal polyps. Eur Arch Otorhinolaryngol. (2015) 272:1955-60. doi: 10.1007/s00405-014-3290-1

53. Wang J, Homer RJ, Hong L, Cohn L, Lee CG, Jung S, et al. IL11 Selectively Inhibits aeroallergen-induced pulmonary eosinophilia and Th2 cytokine production. J Immunol. (2000) 165:2222-31. doi: 10.4049/jimmunol.165.4.2222

54. Fulkerson PC, Zhu H, Williams DA, Zimmermann N, Rothenberg ME. CXCL9 inhibits eosinophil responses by a CCR3- and Rac2-dependent mechanism. Blood. (2005) 106:436-43. doi: 10.1182/blood-2005-02-0489

55. White SR, Kulp GV, Spaethe SM, Van Alstyne E, Leff AR. A kinetic assay for eosinophil peroxidase activity in eosinophils and eosinophil conditioned media. J Immunol Methods. (1991) 144:257-63. doi: 10.1016/0022-1759(91)90094-V

56. Plunkett $\mathrm{CH}$, Nagler $\mathrm{CR}$. The influence of the microbiome on allergic sensitization to food. J Immunol. (2017) 198:581-9. doi: 10.4049/ jimmunol.1601266

57. Pascal M, Perez-Gordo M, Caballero T, Escribese MM, Lopez Longo MN, Luengo O, et al. Microbiome and allergic diseases. Front Immunol. (2018) 9:1584. doi: 10.3389/fimmu.2018.01584

58. Zimmermann P, Messina N, Mohn WW, Finlay BB, Curtis N. Association between the intestinal microbiota and allergic sensitization, eczema, and asthma: a systematic review. J Allergy Clin Immunol. (2019) 143:467-85. doi: 10.1016/j.jaci.2018.09.025

59. Feehley T, Plunkett CH, Bao R, Choi Hong SM, Culleen E, et al. Healthy infants harbor intestinal bacteria that protect against food allergy. Nat Med. (2019) 25:448-53. doi: 10.1038/s41591-018-0324-z

60. McCoy KD, Ignacio A, Geuking MB. Microbiota and Type 2 immune responses. Curr Opin Immunol. (2018) 54:20-7. doi: 10.1016/j.coi.2018.05.009

61. Stefka AT, Feehley T, Tripathi P, Qiu J, McCoy K, Mazmanian SK, et al. Commensal bacteria protect against food allergen sensitization. Proc Natl Acad Sci USA. (2014) 111:13145-50. doi: 10.1073/pnas.1412008111

62. Arias K, Chu DK, Flader K, Botelho F, Walker T, Arias N, et al. Distinct immune effector pathways contribute to the full expression of peanut-induced anaphylactic reactions in mice. J Allergy Clin Immunol. (2011) 127:1552-61 el. doi: 10.1016/j.jaci.2011.03.044

63. Kong J, Chalcraft K, Mandur TS, Jimenez-Saiz R, Walker TD, Goncharova $\mathrm{S}$, et al. Comprehensive metabolomics identifies the alarmin uric acid as a critical signal for the induction of peanut allergy. Allergy. (2015) 70:495-505. doi: 10.1111/all.12579

64. Travers J, Rothenberg ME. Eosinophils in mucosal immune responses. Mucosal Immunol. (2015) 8:464-75. doi: 10.1038/mi.2015.2

65. Kita H. Eosinophils: multifaceted biological properties and roles in health and disease. Immunol Rev. (2011) 242:161-77. doi: $10.1111 /$ j.1600-065X.2011.01026.x

66. Mowat AM, Bain CC. News \& highlights. Mucosal Immunol. (2010) 3:420-1. doi: 10.1038/mi.2010.24

67. Mishra, Hogan SP, Lee JJ, Foster PS, Rothenberg ME. Fundamental signals that regulate eosinophil homing to the gastrointestinal tract. J Clin Invest. (1999) 103:1719-27. doi: 10.1172/JCI6560

68. Szantho E, Karai B, Ivady G, Bedekovics J, Szegedi I, Petras M, et al. Comparative analysis of multicolor flow cytometry and immunohistochemistry for the detection of disseminated tumor cells. 
Appl Immunohistochem Mol Morphol. (2018) 26:305-15. doi: 10.1097/ PAI.0000000000000519

69. Menezes JS, Andrade MC, Senra B, Rodrigues VS, Vaz NM, Faria AM. Immunological activities are modulated by enteral administration of an elemental diet in mice. Clin Nutr. (2006) 25:643-52. doi: 10.1016/j.clnu.2006.01.005

70. Fulkerson PC, Zimmermann N, Brandt EB, Muntel EE, Doepker MP, Kavanaugh JL, et al. Negative regulation of eosinophil recruitment to the lung by the chemokine monokine induced by IFN-gamma (Mig, CXCL9). Proc Natl Acad Sci USA. (2004) 101:1987-92. doi: 10.1073/pnas.0308544100

71. Martinez-Lopez M, Iborra S, Conde-Garrosa R, Mastrangelo A, Danne C, Mann ER, et al. Microbiota sensing by mincle-syk axis in dendritic cells regulates interleukin-17 and -22 production and promotes intestinal barrier integrity. Immunity. (2019) 50:446-61 e9. doi: 10.1016/j.immuni.2018.12.020

72. Shamri R, Xenakis JJ, Spencer LA. Eosinophils in innate immunity: an evolving story. Cell Tissue Res. (2011) 343:57-83. doi: 10.1007/s00441-010-1049-6

73. Lampinen M, Ronnblom A, Amin K, Kristjansson G, Rorsman F, Sangfelt $\mathrm{P}$, et al. Eosinophil granulocytes are activated during the remission phase of ulcerative colitis. Gut. (2005) 54:1714-20. doi: 10.1136/gut.2005.066423

74. Risnes KR, Belanger K, Murk W, Bracken MB. Antibiotic exposure by 6 months and asthma and allergy at 6 years: findings in a cohort of 1,401 US children. Am J Epidemiol. (2011) 173:310-8. doi: 10.1093/aje/kwq400

75. Russell SL, Gold MJ, Hartmann M, Willing BP, Thorson L, Wlodarska M, et al. Early life antibiotic-driven changes in microbiota enhance susceptibility to allergic asthma. EMBO Rep. (2012) 13:440-7. doi: 10.1038/embor.2012.32
76. Metzler S, Frei R, Schmaußer-Hechfellner E, von Mutius E, Pekkanen J, Karvonen AM, et al. Association between antibiotic treatment during pregnancy and infancy and the development of allergic diseases. Pediatr Allergy Immunol. (2019) 30:423-33. doi: 10.1111/pai.13039

77. Abdel-Gadir A, Stephen-Victor E, Gerber GK, Noval Rivas M, Wang $\mathrm{S}$, Harb $\mathrm{H}$, et al. Microbiota therapy acts via a regulatory $\mathrm{T}$ cell MyD88/ROR $\gamma$ t pathway to suppress food allergy. Nat Med. (2019) 25:1458. doi: 10.1038/s41591-019-0572-6

78. Jiménez-Saiz R, Anipindi VC, Galipeau H, Ellenbogen Y, Chaudhary R, Koenig JF, et al. (2019). Microbial regulation of enteric eosinophils and its impact on tissue remodeling and Th2 immunity. bioRxiv. doi: 10.1101/527473

\section{Conflict of Interest: AH is an employee of MedImmune LLC.}

The remaining authors declare that the research was conducted in the absence of any commercial or financial relationships that could be construed as a potential conflict of interest.

Copyright (c) 2020 Jiménez-Saiz, Anipindi, Galipeau, Ellenbogen, Chaudhary, Koenig, Gordon, Walker, Mandur, Abed, Humbles, Chu, Erjefält, Ask, Verdú and Jordana. This is an open-access article distributed under the terms of the Creative Commons Attribution License (CC BY). The use, distribution or reproduction in other forums is permitted, provided the original author(s) and the copyright owner(s) are credited and that the original publication in this journal is cited, in accordance with accepted academic practice. No use, distribution or reproduction is permitted which does not comply with these terms. 